\title{
ASSOCIATION OF ESTROGEN RECEPTOR A PVU II AND XBAI GENE POLYMORPHISMS WITH BREAST CANCER RISK; RELATION TO THE AGE OF MENARCHE AND MENOPAUSE
}

\author{
Magdy A. AL-Tahhan*, Etewa Rasha L. *, \& Doaa O. Refaat** \\ From Medical Biochemistry*, and General Surgery** Departments \\ Faculty of Medicine-Zagazig University
}

\begin{abstract}
The association of estrogen receptor- $\alpha(E R-\alpha)$ genetic polymorphisms with the risk of breast cancer attracts much attention because ER functions as a hormone-dependent transcriptional regulator, which in turn, plays a significant role in the development of breast cancer. This study was conducted to find if there is an association between genetic polymorphisms in the ER- $\alpha$ gene and breast cancer in Egyptian females and its relation to the age of menarche and menopause. A total of 50 breast cancer Egyptian women and 25 age-matched healthy controls were involved in the study. PvuII and XbaI polymorphisms of ER- $\alpha$ gene were genotyped by polymerase chain reaction restriction fragment length polymorphism. Pp/pp genotypes were found in $84 \%$ of patients and in 56\% of controls; and the homozygous wild PP genotype was found in $16 \%$ of patients, and $44 \%$ of controls. There was highly significant increase in the risk of breast cancer with the presence of PvuII restriction site (Pp/pp genotypes) compared with absence of restriction site (PP genotype) $(P=0.008)$. There was statistically significant decrease in the age of menarche $(P=0.021)$ and insignificant differences in the age of menopause of all participant women with presence of PvuII restriction site. Xx/xx genotypes were found in $84 \%$ of patients and in 76\% of controls; and XX genotype was found in 16\% of patients and in $24 \%$ of controls. There was insignificant difference in genotype frequency of the ER- $\alpha$ XbaI polymorphism between patients and controls $(P=0.157)$. There was statistically very highly significant decrease in the age of menarche $(P<0.001)$ and insignificant differences in the age of menopause of all participant women with presence of XbaI restriction site. From the present study, it could be concluded that genetic polymorphisms in the ER- $\alpha$ gene may play a role in the etiology of breast cancer in Egyptian women and may be a genetic determinants of the age of menarche.
\end{abstract}

\section{INTRODUCTION}

Breast cancer is the most common cancer in women. ${ }^{1}$ The etiology of human breast cancer remains largely unknown. Risk factors associated with breast cancer can be grouped into three broad determinants: family history (hereditary) factors, hormonal and reproductive factors, and environmental (including lifestyle) factors. ${ }^{2}$ Estradiol binds with high affinity to estrogen receptor- $\alpha$ (ER- $\alpha$ ). This binding induces DNA synthesis, cell division, and production of growth factors and progesterone 
receptor proteins. Estrogen and progesterone are essential for normal mammary gland development and function, but their stimulation of breast cell proliferation may be procarcinogenic. Many of the identified risk factors for breast cancer can be explained by their effects on lifetime exposure to estrogen and other hormones. ${ }^{3}$ Prolonged exposure to high estrogen levels, as occurs during early menarche or delayed onset of menopause, has major implications for the breast cancer susceptibility in the women. Hormone related cancers such as breast, endometrial, and ovarian share the same mechanism of carcinogenesis with endogenous and exogenous hormones driving cell proliferation, and thus increasing the opportunity of accumulation of somatic mutations that occur during cell division. ${ }^{4}$

ERs belong to a family of transcription factors, the nuclear receptor superfamily, responsible for mediating the effects of steroids on development, reproduction, proliferation, cellular homeostasis and gene expression. ${ }^{5,6}$ Because ER- $\alpha$ is an important mediator of the hormonal response in estrogen sensitive tissues, the genetic polymorphisms on the ER- $\alpha$ were therefore postulated as the potential risk factors of breast cancer. ${ }^{7}$ The association of genetic polymorphisms in the ER- $\alpha$ and the risk of breast cancer have been of increasing interest. $^{4}$ Several ER- $\alpha$ gene polymorphisms have been reported, among which PvuII and XbaI polymorphisms are the most studied. Several diseases, including breast cancer, $^{\mathbf{8}-12}$ endometrial cancer, ${ }^{13}$ endometriosis, and uterine fibroids ${ }^{\mathbf{1 4}}$ have been evaluated for possible linkage with $P v u I \mathrm{I}$ and $X b a \mathrm{I}$ polymorphisms. Both $P v u \mathrm{II}$ and $X b a \mathrm{I}$ polymorphisms are located in intron 1 of the ER- $\alpha$ gene and are 50 b.p apart. $^{15}$

Most studies on ER- $\alpha$ gene polymorphisms and breast cancer were conducted in the Western Countries $^{8-12}$. Since Egyptian women may have different genotype distributional different level of susceptibility compared with Western women, we conducted a hospital based case control study to examine this issue further by evaluating the potential association between genetic polymorphisms of intron 1 ( $P v u \mathrm{II}$ and $X b a \mathrm{I})$ of ER- $\alpha$ gene and breast cancer risk in Egyptian women and to evaluate whether $P v u I I$ and $X b a \mathrm{I}$ polymorphisms of ER- $\alpha$ are associated with the age of menarche and the onset of menopause.

\section{SUBJECTS \& METHODS}

\section{Patients:}

The current study included 50 unrelated breast cancer cases and 25 age-matched unrelated women free from any malignancy or breast masses and comparable in educational level, and economic status with cases. All participants were collected from the General Surgery Departments in Zagazig University Hospital from June 2008 to January 2010. Diagnosis of breast cancer was based on histopathological examination of tissue biopsy from breast masses. A structured questionnaire was used to elicit detailed information on menstrual and reproductive histories, age of menarche, menopause hormone 
use, dietary habits, prior disease history, weight, and family history of cancer. All participants in the study signed informed consents.

Twenty-eight women were at the menopause. Natural menopause was defined as at least twelve consecutive months of amenorrhea not because of surgery or other obvious causes. ${ }^{\mathbf{1 6}}$

\section{DNA Extraction:}

One $\mathrm{ml}$ blood sample was obtained in EDTA-treated tubes from each participant. Genomic DNA was isolated from whole blood using Biospin Whole Blood Genomic DNA Extraction Kit (Bioer Tech. Co. Biojiang, China). DNA was stored at $20^{\circ} \mathrm{C}$ until use.

Genotyping:

The presence of $P v u \mathrm{II}$ and $X b a \mathrm{I}$ polymorphism within ER- $\alpha$ gene was analyzed using polymerase chain reaction-based restriction fragment length polymorphism (PCR-RFLP) according to the method of Cai et al (2003). ${ }^{17}$ The primers used to determine the PvuII and XbaI polymorphisms included forward primer, 5'-CTG CCA CCC TAT CTG TAT CTT TTC CTA TTC TCC-3'; and reverse primer, 5'-TCT TTC TCT GCC ACC CTG GCG TCG ATT ATC TGA-3'. The PCR was carried out in a total volume of $50 \mu \mathrm{l}$ containing $25 \mathrm{ul}$ of Taq PCR Master Mix containing, $10 \mathrm{X}$ reaction buffer, $1.5 \mathrm{mM} \mathrm{MgCl}_{2}, 200 \mu \mathrm{M}$ of each dNTP and 2.5 units of Taq DNA polymerase (Qiagen GmbH, Hilden, German), 30 pmol of each primer (3 ul of each primer) (Biosource Europe S.A., Belgium, Netherlands, German), $100 \mathrm{ng}$ of template DNA ( $3 \mathrm{ul})$, and $16 \mathrm{ul}$ of sterile double distilled water.
The PCR conditions were as follows: an initial denaturation step at $95{ }^{\circ} \mathrm{C}$ for 5 minutes, followed by 35 cycles of denaturation at $94{ }^{\circ} \mathrm{C}$ for 45 seconds, annealing at $61{ }^{\circ} \mathrm{C}$ for 40 seconds and extension at $72{ }^{\circ} \mathrm{C}$ for 2 minutes, ending with a final extension at $72{ }^{\circ} \mathrm{C}$ for 7 minutes and cooling to $10{ }^{\circ} \mathrm{C}$ using thermal cycler PTC-100 machine (MJ Research, Inc. Watertown, Mass USA).

The PCR products, which contained a part of intron 1 and exon 2 of the ER$\alpha$ gene, were digested respectively with $P v u I I$ and $X b a \mathrm{I}$ restriction enzymes (Fermentas International Inc., Burlington, Ontario, Canada) at $37{ }^{\circ} \mathrm{C}$ overnight, the cleavage products were electrophoresed on $2 \%$ agarose gel using the EC 360 Submarine Gel electrophoresis system (Maxicell, EC 360 M-E-C apparatus Cooperation. St Petersburg Florida USA) and detected by ethidium bromide staining then visualized under UV transillumination with 100 bp ladder (Pharmacia Biotech, USA) and photographed.

$\mathrm{PP}$ and XX genotypes, signifying the absence of restriction sites, gave one $1300 \mathrm{bp}$ fragment. pp genotype, signifying the presence of $P v u \mathrm{II}$ restriction sites on both alleles, was digested into two fragments (850 and $450 \mathrm{bp})$. The $\mathrm{xx}$ genotype was revealed by $X b a \mathrm{I}$ digestion into two fragments (900 and 400 b.p).

\section{Statistical Analysis:}

Statistical analysis was conducted using Statistical Package for Social Sciences version 11 (SPSS Inc., Chicago, USA). $\mathrm{P}$ value was considered statistically significant at $<0.05$, highly significant at $<0.01$, and very highly significant at $<0.001$. The 
Chi-square $\left(X^{2}\right)$ test was used to determine the significance of the difference in allele frequency. Odds ratio (OR) and 95\% confidence interval (CI) were estimated by unconditional logistic regression to evaluate an association between ER- $\alpha$ $P v u \mathrm{II}, \quad X b a \mathrm{I}$ genotypes and breast cancer risk status.

\section{RESULTS}

The ages of the patients ranged from 30-68 years and the age of controls ranged from 32-70 years. There was no statistically significant difference between controls and breast cancer patients as regard age $(\mathrm{P}=$ $0.15)$.

\section{ER- $\alpha$ PvuII Genetic Polymorphism} and Breast Cancer:

PCR-based RFLP assay of the $P v u$ II polymorphism of the ER- $\alpha$ gene is shown in figure 1.

$\mathrm{Pp}$ and $\mathrm{pp}$ genotypes were found in $84 \%$ of patients and in $56 \%$ of controls; and the homozygous wild PP genotype was found in $16 \%$ of patients, and $44 \%$ of controls. With respect of breast cancer development, PP genotype was taken as a reference; comparing patients with controls, there was highly significant increase in the risk of breast cancer with the presence of $P v u$ II restriction site (Pp/pp genotypes) compared with absence of restriction site (PP genotype) $(\mathrm{OR}=4.1$ (95\% CI, 1.412.3), $\mathrm{P}=0.008)$, OR for genotypes Pp was 2.9 (95\% CI, 1.0-8.5) and for pp, it was 1.2 (95\% CI, 0.4-3.3), Table 1.

ER- $\alpha$ XbaI Genetic Polymorphism and Breast Cancer:

PCR-based RFLP assay of the $X b a \mathrm{I}$ polymorphism of the ER- $\alpha$ gene is shown in figure 2.
$\mathrm{Xx}$ and $\mathrm{xx}$ genotypes were found in $84 \%$ of patients and in $76 \%$ of controls; and the homozygous wild XX genotype was found in $16 \%$ of patients, and $24 \%$ of controls. With respect of breast cancer development, $\mathrm{XX}$ genotype was taken as a reference; comparing patients with controls, there was insignificant increase in the risk of breast cancer with the presence of $X b a \mathrm{I}$ restriction site $(\mathrm{Xx} / \mathrm{xx}$ genotypes) compared with absence of restriction site (XX genotype) (Odd ratios (ORs) was 1.6 (95\% CI, 0.5-5.4), P = 0.157), ORs for genotypes $\mathrm{Xx}$ was $1.2(95 \% \mathrm{CI}, 0.4$ $3.1)$ and for $\mathrm{xx}$, it was 1.1 (95\% CI, 0.5-3.2), Table 2.

Relation of ER-a Polymorphisms and Age of Menarche:

In all participants, the mean age of menarche in PP genotype was $13.9 \pm 1.6$ years; while in $P p / p p$ genotypes, it was $12.9 \pm 1.6$ years. There was statistically significant decrease in the mean age of menarche of women with presence of $P v u$ II restriction site (Pp/pp genotypes) compared with women with absence of restriction site ( $\mathrm{PP}$ genotype) $(\mathrm{P}=$ $0.021)$. The mean age of menarche of $\mathrm{XX}$ genotype was $14.8 \pm 1.5$ years; while in $\mathrm{Xx} / \mathrm{xx}$ genotypes, it was $12.9 \pm 1.5$ years. There was statistically very highly significant decrease in the mean age of menarche of women with presence of $X b a \mathrm{I}$ restriction site $(\mathrm{Xx} / \mathrm{xx}$ genotypes) compared with women with absence of restriction site (XX genotype) $(\mathrm{P}<0.001)$, Table 3 .

Relation of ER-a Polymorphisms and Age of Menopause:

The mean age of menopause in PP genotype was $47.6 \pm 2.9$ years, while the mean age of menopause in $\mathrm{Pp} / \mathrm{pp}$ 
genotypes was $48.2 \pm 5.3$ years. There was statistically insignificant difference in the age of menopause of women with presence of $P v u \mathrm{II}$ restriction site (Pp/pp genotypes) compared with women with absence of restriction site ( $\mathrm{PP}$ genotype) $(\mathrm{P}=$ 0.755). The mean age of the menopause in women carrying $\mathrm{XX}$, genotype was $47.0 \pm 4.5$ years while the mean age of women carrying $\mathrm{Xx} / \mathrm{xx}$ genotypes was $48.2 \pm 4.7$ years. There was statistically insignificant difference in the age of menopause of women with presence of Xbal restriction site $(\mathrm{Xx} / \mathrm{xx}$ genotypes $)$ compared with women with absence of restriction site (XX genotype) $(\mathrm{P}=$ $0.61)$, Table 4.

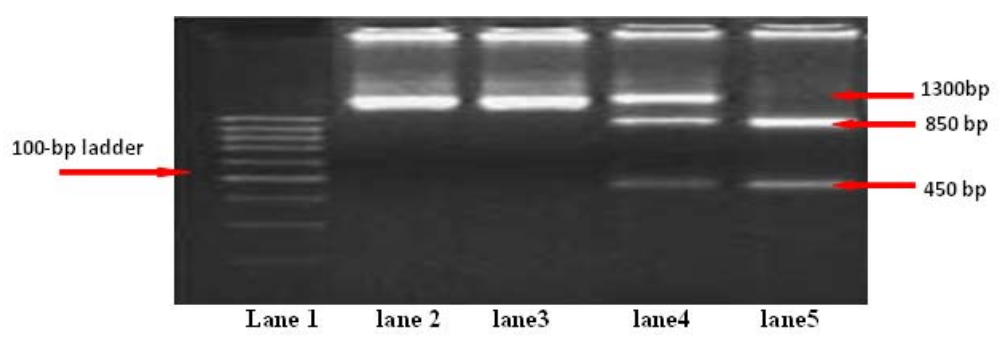

Figure 1: PCR -RFLP analysis of the PvuII polymorphism of the ER- $\alpha$ gene. Lane 1, 100-bp DNA ladder (Pharmacia Biotech, USA); Lane 2, 3; no polymorphism (PP) indicating absence of $P v u \mathrm{II}$ restriction site from both alleles giving one band at 1300 bp, Lane 4; heterozygous (Pp); indicating the presence of PvuII restriction sites on one of the two alleles, giving three bands at 1300,850 and $450 \mathrm{~kb}$ Lane 5 , homozygous (pp); indicating the presence of $P v u I I$ restriction site on both alleles, giving two bands at 850 and $450 \mathrm{~kb}$.

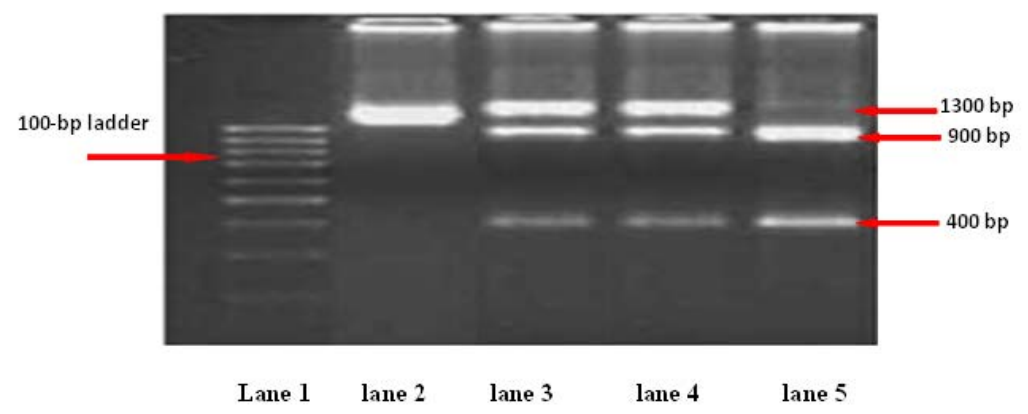

Figure 2: PCR -RFLP assay of the $X b a \mathrm{I}$ polymorphism of the ER- $\alpha$ gene. Lane 1, 100-bp DNA ladder (Pharmacia Biotech, USA); Lane 2; no polymorphism (XX); indicating absence of $X b a \mathrm{I}$ restriction site from both alleles giving one band at 1300 bp Lane 3, 4; heterozygous (Xx), indicating the presence of $X b a \mathrm{I}$ restriction site on one of the two alleles, giving three bands at 1300, 900 and 400 bp Lane 5; homozygous $(\mathrm{xx})$ indicating the presence of $X b a \mathrm{I}$ restriction site on both alleles, giving two bands at 900 and $400 \mathrm{bp}$. 
Table 1; Genotype distribution of estrogen receptor- $\alpha$ (ER- $\alpha$ ) PvuII polymorphism in breast cancer cases $(n=50)$ and controls $(n=25)$.

\begin{tabular}{|l|l|l|l|l|}
\hline $\begin{array}{l}\text { Genotypes of ER- } \boldsymbol{\alpha} \\
\text { PvuII }\end{array}$ & $\begin{array}{l}\text { Controls, } \\
\text { n (\%) }\end{array}$ & $\begin{array}{l}\text { Breast cancer } \\
\text { patients, n }(\%)\end{array}$ & $\begin{array}{l}\text { Odds } \\
\text { ratio }\end{array}$ & $\begin{array}{l}\text { 95\% confidence } \\
\text { interval }\end{array}$ \\
\hline PP & $11(44 \%)$ & $8(16 \%)$ & 1.0 & Ref. \\
Pp/pp & $14(56 \%)$ & $42(84 \%)$ & 4.1 & $1.4-12.3$ \\
$\quad$ Pp & $6(24 \%)$ & $24(48 \%)$ & 2.9 & $1.0-8.5$ \\
pp & $8(32 \%)$ & $18(36 \%)$ & 1.2 & $0.4-3.3$ \\
\hline P value & 0.008 & \multicolumn{4}{|l}{} \\
\hline
\end{tabular}

* between PP genotype vs both Pp/pp genotypes.

Table 2; Genotype distribution of estrogen receptor- $\alpha$ (ER- $\alpha$ ) XbaI polymorphism in breast cancer cases $(n=50)$ and controls $(n=25)$.

\begin{tabular}{|l|l|l|l|l|}
\hline $\begin{array}{l}\text { Genotypes of } \\
\text { ER- } \boldsymbol{\alpha} \text { XbaI }\end{array}$ & $\begin{array}{l}\text { Controls, } \\
\mathrm{n}(\%)\end{array}$ & $\begin{array}{l}\text { Breast cancer } \\
\text { patients, } \mathrm{n}(\%)\end{array}$ & $\begin{array}{l}\text { Odds } \\
\text { ratio }\end{array}$ & $\begin{array}{l}\text { 95\% confidence } \\
\text { interval }\end{array}$ \\
\hline $\mathbf{X X}$ & $6(24 \%)$ & $8(16 \%)$ & 1.0 & Ref. \\
$\mathbf{X x} / \mathbf{x x}$, & $19(76 \%)$ & $42(84 \%)$ & 1.6 & $0.5-5.4$ \\
$\quad \mathbf{X x}$ & $10(40 \%)$ & $22(44 \%)$ & 1.2 & $0.4-3.1$ \\
$\quad \mathbf{x x}$ & $9(36 \%)$ & $20(40 \%)$ & 1.1 & $0.4-3.2$ \\
\hline P value & 0.157 & \multicolumn{4}{|l}{} \\
\hline
\end{tabular}

*between XX genotype vs both Xx/xx genotypes.

Table 3; Relationship between polymorphisms of estrogen receptor- $\alpha$ (ER- $\alpha$ ) $P v u I I$ and $X b a l$ and age of menarche (years) in all participants $(n=75)$.

\begin{tabular}{|c|l|l|l|}
\hline ER- $\alpha$ polymorphisms & Number & $\begin{array}{l}\text { Age of menarche, } \\
\text { mean } \pm \text { SD }\end{array}$ & P \\
\hline $\begin{array}{c}\text { Genotypes of ER- } \boldsymbol{\alpha} \text { PvuII } \\
\text { PP }\end{array}$ & 23 & $13.9 \pm 1.6$ & 0.021 \\
Pp/pp & 52 & $12.9 \pm 1.6$ & \\
\hline $\begin{array}{c}\text { Genotypes of ER- } \boldsymbol{\alpha} \text { XbaI } \\
\text { XX }\end{array}$ & 13 & $14.8 \pm 1.5$ & $<0.001$ \\
Xx/xx & 62 & $12.9 \pm 1.5$ & \\
\hline
\end{tabular}

Table 4; Relationship between polymorphisms of estrogen receptor- $\alpha$ (ER- $\alpha$ ) $P v u I I$ and $X b a l$ and age of menopause (years) in all participants $(n=28)$.

\begin{tabular}{|l|l|l|l|}
\hline ER- $\boldsymbol{\alpha}$ polymorphisms & Number & $\begin{array}{l}\text { Age of menopause, } \\
\text { mean } \pm \text { SD }\end{array}$ & P \\
\hline $\begin{array}{c}\text { Genotypes of ER- } \boldsymbol{\alpha} \boldsymbol{P} \boldsymbol{v} \boldsymbol{u} \text { II } \\
\text { PPp/pp }\end{array}$ & 9 & $47.6 \pm 2.9$ & \\
& 19 & $48.2 \pm 5.3$ & 0.755 \\
\hline Genotypes of ER- $\boldsymbol{\alpha}$ Xba I & 5 & $47.0 \pm 4.5$ & 0.617 \\
XX & 23 & $48.2 \pm 4.7$ & \\
Xx/xx & &
\end{tabular}




\section{DISCUSSION}

ER- $\alpha$ is believed to be major participator in breast cancer carcinogenesis, so the genetic polymorphisms on the ER- $\alpha$ are postulated as potential risk factors of breast cancer. Both $P v u \mathrm{II}$ and $\mathrm{XbaI}$ polymorphisms are located in intron 1 of the ER- $\alpha$ gene and are 50 bp apart. $^{15,18}$ Studies in Western and Asian women have revealed, however, inconsistent associations of ER- $\alpha \quad P v u I I$ and ER- $\alpha \quad X b a \mathrm{I}$ polymorphisms with breast cancer $^{7,9,17}$. In the current study we investigated $P v u \mathrm{II}$ and $X b a \mathrm{I}$ polymorphisms in cancer breast in Egyptian women and their relation to age of menarche and menopause as the $X b a \mathrm{I}$ and $P v u \mathrm{II}$ polymorphisms of the ER- $\alpha$ gene have also implicated in major diseases where life time estrogen exposure is considered to be a potentially important risk modifier. We found that the polymorphism at the $P v u I I$ restriction site $(\mathrm{Pp} / \mathrm{pp}$ genotype) was associated with statistically highly significant increase in the risk of breast cancer. The $X b a \mathrm{I}$ restriction site $(\mathrm{Xx} / \mathrm{xx}$ genotype) was associated with insignificant increased risk for breast cancer. Possible explanations of how breast cancer risk is affected by the intronic $P v u \mathrm{II}$ polymorphism of the ER- $\alpha$. gene include: (a) the intronic polymorphism may be in linkage disequilibrium with exon alteration, which affects ER protein function ${ }^{19}$; (b) the PvuII polymorphism in the ER- $\alpha$ gene may be linked with the alteration of another unidentified gene adjacent to the ER- $\alpha$ gene, which increases breast cancer risk $^{19}$; (c) intronic changes in gene sequence may have an impact on the expression of other genes by influencing the transcription and/or stability of mRNA of those genes $^{\mathbf{2 0 , 2 1}}$; (d) and some introns contain regulatory sequences such as enhancers, which affect the levels of expression through transcriptional regulation. ${ }^{\mathbf{2 2 , 2 3}}$

Hormone receptors in the breast could influence susceptibility to the effects of hormone as estrogens exert their effects through the estrogen receptors. ${ }^{24,25}$ Some polymorphisms in the genes coding for these receptors may change the expression of the receptors and may, therefore, modify the effect of hormone on mammographic density and hence breast cancer. ${ }^{26}$ Two studies have suggested that the ER- $\alpha$ PvuII $\mathrm{p}$ allele increases ER- $\alpha$ transcription, ${ }^{27,28}$ whereas another study has suggested that the $P v u I I \mathrm{p}$ allele and the $X b a \mathrm{I} \quad \mathrm{x}$ allele increase transcription of ER- $\alpha .^{29}$ These results indicate that $P v u \mathrm{II}$ and $X b a \mathrm{I}$ polymorphisms are involved in the production of ER- $\alpha$, but the exact function needs to be clarified.

The results of the present study are in agreement with those of Onland-Moret et al. (2006) who have found increased breast cancer risk related to the $P v u I I$ polymorphism $\mathrm{p}$ allele, and insignificant elevated risk for the $X b a \mathrm{I}$ polymorphism $x$ allele. ${ }^{30}$ A large-scale population-based case-control study conducted in urban Shanghai has found that the $\mathrm{pp}$ genotype of $P v u \mathrm{II}$ was associated with a relative risk of 1.4 when compared with women with PP genotype and the $X b a \mathrm{I}$ polymorphism was associated with insignificant increased risk for breast 
cancer only among older or postmenopausal women. has found that the PvuII polymorphism and ER status might have an interactive effect in breast cancer survival among the Shanghai women. ${ }^{31}$ Results of Shen $\boldsymbol{e t}$ al. (2006) indicated that both ER- $\alpha P v u \mathrm{II}$ $\mathrm{Pp} / \mathrm{pp}$ and ER- $\alpha$ XbaI $\mathrm{Xx} / \mathrm{xx}$ genotypes may increase the risk of breast cancer in women with family history of breast canccer. ${ }^{7}$ Parle et al . (1989) have found that the $p$ allele of $P v u$ II was related to a younger age at breast cancer diagnosis. ${ }^{8}$ Yaich et al . (1992) examined the PvuII polymorphism in the tumor tissue of 257 primary breast cancer patients and 140 peripheral blood DNA samples from women without breast cancer; breast cancer patients with pp genotype were significantly younger than women with PP or Pp genotype at the time of cancer diagnosis. ${ }^{15}$ Shin et al. (2002) have reported that women with $\mathrm{xx}$ genotype of $X b a \mathrm{I}$ has 2.38-fold risk to develop breast cancer compared with women with $\mathrm{XX}$ genotype. ${ }^{10}$

However, contradictory to the present study results, Andersen et al . (1994) have found that allele frequencies of the $P v u \mathrm{II}$ polymorphism did not differ between breast cancer cases and controls in Norwegian women. The frequency of the $\mathrm{x}$ allele of the $X b a \mathrm{I}$ polymorphism among breast cancer patients, however, was 1.4 times of that for controls. Among the breast cancer patients, there was an association of borderline significance between the $X b a \mathrm{I}$ restriction site and older age at onset. ${ }^{9}$ Sobczuk et al (2008) have concluded that the PvuII polymorphism of ER- $\alpha$ gene as well as $X b a \mathrm{I}$ polymorphism may not be linked with appearance and development of breast cancer. The inconsistency in the results may be due to the differences in study design and study population. ${ }^{32}$

Menarche is regulated by a variety of environmental and genetic factors. Twin analyses have estimated that genetic effects may be more important

parameters. ${ }^{33,34}$ Such studies have indicated that $53-74 \%$ of the variation in age of menarche may be attributed to genetic effects. Estrogen exposure of tissues mediated via the ER may be an important determinant of menarche and may be genetically determined. Conversely, the age of menarche may then influence the total duration of tissue estrogen exposure and subsequent susceptibility of breast cancer.

In the current study, we found that there was statistically significant decrease in the age of menarche of women with presence of $P v u \mathrm{II}$ restriction site (Pp/pp genotypes) compared with women with absence of restriction site (PP genotype) and statistically very highly significant decrease in the age of menarche of women with presence of $X b a \mathrm{I}$ restriction site $(\mathrm{Xx} / \mathrm{xx}$ genotypes $)$ compared with women with absence of restriction site (XX genotype).These results are consistent with that of Stavrou et al ( $\mathbf{( 2 0 0 2}^{\mathbf{3 5}}$ who found delay in the age of menarche in subjects homozygous for PP genotypes. $^{35}$ Also XX homozygotes are protected from breast cancer and endometrial 
cancer., ${ }^{9,13}$ An insignificant trend for protection against endometrial cancer has also been seen for PP homozygotes. ${ }^{13}$ Part of the protective effect may be mediated by a delayed menarche. A delayed menarche is a strong protective factor against breast cancer and is related to reduced lifetime estrogen exposure of the target tissues, as has been shown in several studies. ${ }^{\mathbf{9}, 13,35}$ Also this have been found by Hsieh et al 1990 before the widespread advent of oral contraceptives, which may also contribute to the cumulative estrogen exposure. $^{36}$

The biological pathway for $X b a \mathrm{I}$ and $P v u$ II that may affect the age of menarche is not well known. Restriction sites of both polymorphisms are located in the intron 1 of the ER- $\alpha$ gene. Some introns contain regulatory sequences such as enhancers, ${ }^{37,23}$ and binding sites for elements that regulate the level of gene expression and thus also affect protein synthesis. ${ }^{\mathbf{3 8}}$

Alternatively, the observed association may reflect linkage disequilibrium with some other functional polymorphism in the $X b a \mathrm{I}$ vicinity. Regardless of the exact mechanism, if ER- $\alpha$ gene polymorphisms can alter the estrogenic biological activity at the cellular level; this may influence the maturation of the hypothalamicpituitary-gonadal axis which determines the onset of menarche. ${ }^{35}$

The present study showed insignificant association between ER$\alpha$ gene $P v u I I$ and $X b a \mathrm{I}$ polymorphisms and age at menopause. Weel et al . (1999) found that $P v u$ II polymorphism of the ER- $\alpha$ gene was associated with early onset of menopause in a Dutch population. Women carrying the PP genotype of the PvuII polymorphism were found to have a 1.1-year earlier onset of menopause compared to women with the pp genotype. ${ }^{39}$ However, two other studies, one carried out in a Japanese population and the other in also a Dutch population, could not replicate this finding. ${ }^{\mathbf{4 0 , 4 1}}$ So the results of the present study are in agreement with the last two studies.

Weel et al . (1999) were the first to establish an association between an ER- $\alpha$ gene polymorphism and age at menopause. ${ }^{39}$ Gene variants might be associated with different relative risks in different populations and then the non-replication might result from real biological differences. This could explain the difference in the results of other studies in Caucasian ${ }^{39}$ and Asian $^{40}$ populations. However, ethnic difference does not explain the different results obtained in Dutch population by Weel et al . (1999) ${ }^{39}$ and Kok et al . (2005). ${ }^{41}$ Complex traits are etiologically heterogeneous as they are the result of multiple genetic and environmental components. Non-replication might be due to the small magnitude of relative risks that are likely to be detected in candidate gene studies of complex traits. Furthermore, confounding, bias and misclassification are more likely to obscure small to moderate relative risks than larger relative risks. ${ }^{42}$

Though some positive results had been observed in the present study, but it still had some limitations. Firstly, the present study was a hospital-based study. Secondary, relatively small sample size, and it 
might prevent some observed effects of genetic polymorphisms from reaching statistical significance. So, the result obtained from this study cannot be generalized unless similar studies are replicated and validated in different populations.

In summary, in the present study, we observed a significantly increased risk of breast cancer associated with ER- $\alpha$ $P v u$ II polymorphism, there was no appreciable difference in genotype frequency of the ER- $\alpha \quad X b a \mathrm{I}$ polymorphism between controls and cases. Moreover ER- $\alpha$ PvuII, XbaI polymorphisms affect the age of menarche which may be a predisposing factor for increased estrogen life time exposure which might be a risk factor for breast cancer.

\section{REFERENCES}

1. Parkin, D.M.; Bray, F.I., and Devesa, S.S. (2001): Cancer burden in the year 2000. The global picture. Eur. J. Cancer, 37:S4-S66.

2. Lichtenstein, P.; Holm, N.; Verkasalo, P.K.; Iliadou, A.; Kaprio, J.; Koskenvuo, M.; Pukka, E.; Skytthe, A., and Hemminki, K. (2000): Environmental and heritable factors in the causation of cancer-analyses of cohorts of twins from Sweden, Denmark, and Finland. N. Engl. J. Med., 343:78-85.

3. Henderson, B.E., and Feigelson, H.S. (2000): Hormonal carcinogenesis. Carcinogenesis, 21:427-433.
4. Zhang, W., and Yu, Y.Y. (2007): Polymorphisms of short tandem repeat of genes and breast cancer susceptibility. EJSO, 33:529-534.

5. Ingles, S.A.; Ross, R.K., and Yu, M.C. (1977): Association of prostate cancer risk with genetic polymorphisms in vitamin D receptor and androgen receptor. J. Nat. Cancer Inst., 89:166-170.

6. Ascenzi, P.; Bocedi, A., and Marino, M. (2006): Structurefunction relationship of estrogen receptor $\alpha$ and $\mathrm{P}$ : impact on human health. Mol. Aspects Med., 27:299-402.

7. Shen, Y.; Li, D.; Wu, J.; Zhang. Z., and Gao, E. (2006): Joint Effects of the CYP1A1 Mspl, ERa PvuII, and ER $\alpha X b a l$ Polymorphisms on the Risk of breast cancer: Results from a Population-Based Case-Control Study in Shanghai, China. Cancer Epidemiol. Biomarkers Prev., 15:342-347.

8. Parle, F.F.; Cavener, D.R., and Dupont, W.D. (1989): Genomic DNA analysis of the estrogen receptor gene in breast cancer. Breast Cancer Res. Treat., 14:5764.

9. Andersen, T.I.; Heimdal, K.R.; Skrede, M.; Tveit, K.; Berg, K., and Borresen, A.L. (1994): Estrogen receptor (ESR) polymorphisms and breast cancer susceptibility. Hum. Genet., 94:665-670.

10. Shin, A.; Kirn, S.U.; Nishio, H.; Lee, M.J.; Park, S.K.; Noh, D.Y.; Choe, K.J.; Ahn, S.H.; Kang, D., and Yoo, K.Y. (2002): Estrogen receptor - 
polymorphism and breast cancer risk. Proc. Am. Assoc. Cancer Res., 42:239-242.

11. Siddig, A.; Mohamed, A.O.; Awad, S.; Hassan, A.H.; Zilahi, E.; Al-Haj, M.; Bernsen, R., and Adem, A. (2008): Estrogen receptor alpha gene polymorphism and breast cancer. Ann. N. Y. Acad. Sci., 1138:95107.

12. Gaudet, M.M.; Milne, R.L.; Cox, A.; Camp, N.J.; Goode, E.L., and Humphreys, M.K. (2009): Five polymorphisms and breast cancer risk: results from the Breast Cancer Association Consortium. Cancer Epidemiol. Biomarkers Prev., 18:1610-6.

13. Weiderpass, E.; Persson, I.; Melhus, H.; Wedren, S.; Kindmark, A., and Baron, J.A. (2000): Estrogen receptor $\alpha$ gene polymorphisms and endometrial cancer risk. Carcinogenesis (Lond), 21: 623-627.

14. Govindan, S.; Shaik, N.A.; Vedicherla, B.; Kodati, V.; Rao, K.P., and Hasan, Q. (2009): Estrogen receptor $-\alpha$ gene $(\mathrm{T} / \mathrm{C})$ $P v u$ II polymorphism in endometriosis and uterine fibroids. Dis. Markers 26:149-54.

15. Yaich, L.; Dupont, W. D.; Cavener, D. R., and Parl, F. (1992): Analysis of the PvuII restriction fragment-length polymorphism and exon structure of the estrogen receptor gene in breast cancer and peripheral blood Cancer Res., 52: 77-83.

16. World Health Organization Scientific Group (1996): Research on the menopause in the 1990s, pp 866.
17. Cai, Q.; Shu, X.O., and Jin, F. (2003): Genetic polymorphisms in the estrogen receptor $\alpha$ gene and risk of breast cancer: results from the Shanghai Breast Cancer Study. Cancer Epidemiol. Biomarkers. Prev., 12:853-859.

18. Zuppan, P.J.; Hall, J.M.; Ponglikitmongkol, M.; Spielman, R., and King, M.C. (1989): Polymorphisms at the estrogen receptor (ESR) locus and linkage relationships on chromosome 6q. Cytogenet. Cell Genet., 51:149-165.

19. Kobayashi, S.; Inoue, S.; Hosoi,T.; Ouchi, Y.; Shiraki, M., and Orimo, H. (1996): Association of bone mineral density with polymorphism of the estrogen receptor gene. J. Bone Miner. Res., 11:306-311.

20. Blaszyk, H.; Hartmann, A.; Sommer, S.S., and Kovach, J.S. (1996): A polymorphism but no mutations in the GADD45 gene in breast cancers. Hum. Gene ., 97:543-547.

21. Goessl, C.; Plaschke, J.; Pistorius, S.; Hahn, M.; Frank,S.; Hampi, M.; Gorgens, H.; Koch, R.; Saeger, H.D., and Schackert, H.K. (1997): An intronic germ line transition in the HNPCC gene hMSH2 is associated with sporadic colorectal cancer. Eur. J. Cancer, 33:1869-1874.

22. Aronow, B.; Lattier, D.; Silbiger, R.; Dusing, M.; Button, J.; Jones ,G.; Stock, J.; McNeish, J.; Potter, S.; Witte, D., and Wiginton, D. (1989): Evidence for a complex regulatory array in the first intron 
of the human adenosine deaminase gene. Gene. Dev., 3:1384-1400.

23. Gasch, A.; Hinz, U., and Renkawitz-Pohl, R. (1989): Intron and upstream sequences regulate expression of the Drosophila - 3-tubulin gene in the visceral and somatic musculature, respectively. Proc. Nat. Acad. Sci., 86:3215-3218.

24. Katzenellenbogen, B.S. (1996): Estrogen receptors: bioactivities aninteractions with cell signaling pathways. Biol. Reprod., 54:287293.

25. Leonhardt, S.A.; Boonyaratanakornkit, V., and Edwards, Progesterone transcription transcription D.P. (2003): receptor and nonsignaling mechanisms. Steroids, 68:761770.

26. Duijnhoven, F.J.; Peeters, P.; Warren, R.M.; Bingham, S.A.; Uitterlinden, A.G.; Noord, P.A.; Monninkhof, E.M.; Grobbee, D.E., and Gils, C.H (2006): Influence of Estrogen Receptor $\alpha$ and Progesterone Receptor Polymorphisms on the Effects of Hormone Therapy on the Mammographic Density. Cancer Epidemiol. Biomarkers. Prev., 15:462-467.

27. Herrington, D.M.; Howard, T.D., and Brosnihan, K.B. (2002): Common estrogen receptor polymorphism augments effects of hormone replacement therapy on E-selectin but not Creactive protein. Circulation, 105:1879-1882.
28. Schuit, S.C.; Oei, H.H., and Witteman, J.C. (2004): Estrogen receptor $\alpha$ gene polymorphisms and risk of myocardial infarction. JAMA, 291:2969-2977.

29. Maruyama, H.; Toji, H.; Harrington, C.R.; Sasaki, K.; Izumi, Y.; Ohnuma, T.; Arai, H.; Yasuda, M.; Tanaka, C.; Emson, P.C.; Nakamura, S., and Kawakami, H. (2000): Lack of an association of estrogen receptor-gene polymorphisms and transcriptional activity with Alzheimer's disease. Arch. Neurol., 57:236-240.

30. Onland-Moret, N.C.; van Gils, C.H.; Roest, M.; Grobbee, D.E., and Peeters, P.H. (2006): The estrogen receptor $\alpha$ gene and breast cancer risk (The Netherland). Cancer Cases Control, 16:1195-1202.

31. Boyapati, S.M.; Shu,X.O.; Ruan, Z.X.; Cai ,Q.; Smith, J.R.; Wen, W.; Gao,Y.T., and Zheng, W. (2005): Polymorphisms in ER-alpha gene interact with estrogen receptor status in breast cancer survival. Clin. Cancer Res., 11:1093-1098.

32. Sobczuk, A.; Pertyński, T.; Smolarz, B., and RomanowiczMakowska, H. (2008): The analysis of estrogen receptor alpha (ER-alpha) gene Pvull and Xbal polymorphisms in postmenopausal women with breast cancer. Pol. Merkur Lekarski., 25(145):43-45.

33. Treloar, S.A., and Martin, N.G. (1990): Age at menarche as a fitress trail: non additive genetic variance detected in a large twin 
sample. Am. J. Hum. Genet, 47:137-148.

34. Kaprio, J.; Rimpela, A.; Winter, T.; Viken, J.R.; Rimpela, M., and Rose, J.R. (1995): Common genetic influences on BMI and age at menarche. Hum. Biol., 67:739753.

35. Stavrou, I.; Zois, C.; loannidis, J.P.A., and Tsatsoulis, A. (2002): Association of polymorphisms of estrogen receptor $\alpha$ gene with the age of menarche. Human Reproduction, 17:1101-1105.

36. Hsieh, C.C.; Trichopoulos, D.; Katsouyanni, K., and Yuasa, S. (1990): Age at menarche, age at menopause, height and obesity as risk factors for breast cancer: associations and interactions in an international case-control study. Int. J. Cancer 46:796-800.

37. 37. Bornstein, P.; McKay, J.; Morishima, J.K.; Devarayalu, S., and Gelinas, R.E. (1987): Regulatory elements in the first intron contribute to transcriptional control of the human collagen alpha 1 (I) collagen gene. Proc. Nat Acad. Sci., 84: 8869-8873.

38. Laurie, C.C., and Stam, L.F. (1994): The effect of an intronic polymorphism on alcohol dehydrogenase expression in Drosophila melanogaster. Genetics 138:379-385.
39. Weel, A.E.; Uitterlinden, A.; Westrndo, L.C.; Burger, H.; Schuit, Sc.; Hofman, A.; Helmerhorst, T.J.; Leeuwen, J.P., and Pols, H.A. (1999): Estrogen receptor polymorphism predicts the onset of natural and surgical menopause. J. Clin. Endocrinol. Metab., 4:3146-3150.

40. Gorai, I.; Tanaka, K.; Inada, M.; Morinaga, H.; Uchiyama, Y.; Kikuchi, R.; Chaki, O., and Hirahara, F. (2003): Estrogenmetabolizing gene polymorphisms, but not estrogen receptor-alpha gene polymorphisms, are associated with the onset of menarche in healthy postmenopausal Japanese women. J. Clin. Endocrinol. Metab., 88:799-803.

41. Kok, H.S.; Onland-Moret, N.C.; Van Asselt, K.M.; van Gils CH, van der Schouw YT, Grobbee, D.E., and Peeters, P.H. (2005): No association of estrogen receptor alpha and cytochrome P 450c 17 alpha polymorphisms with age at menopause in a Dutch cohort. Hum.Reprod., 20:536-542.

42. Tabor, H.K.; Risch, N.J., and Myers, R.M. (2002): Opinion: Candidate-gene approaches for studying complex genetic traits: practical considerations. Nat. Rev. Genet., 3:391-397. 


$$
\begin{aligned}
& \text { إرتباط الأثكال المتعددة لجين مستقبلات الأستروجين ألفا وخطر الإصابة بسرطان }
\end{aligned}
$$

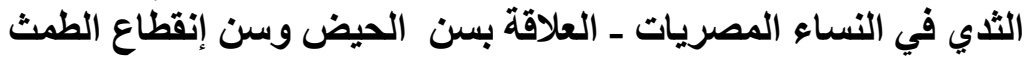

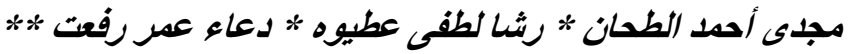

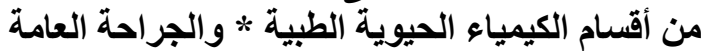

$$
\begin{aligned}
& \text { كلية الطب - جامعة الزقازيق الجيق }
\end{aligned}
$$

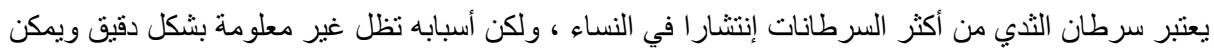

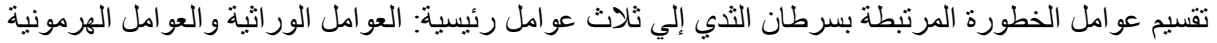

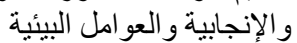

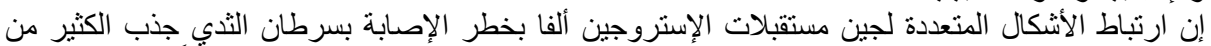

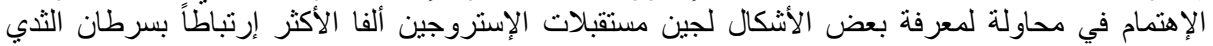

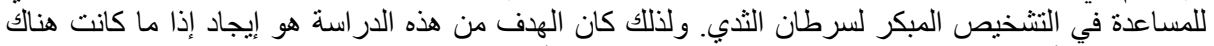

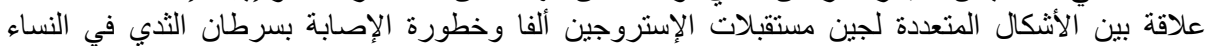

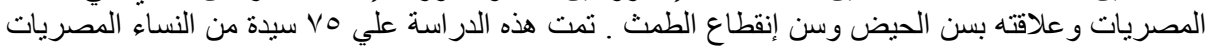

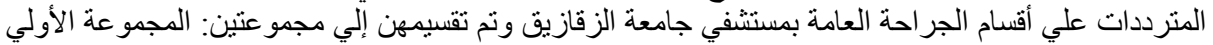

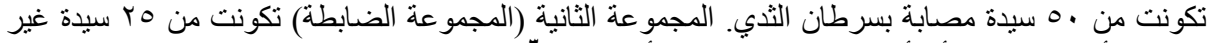

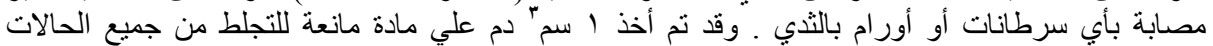

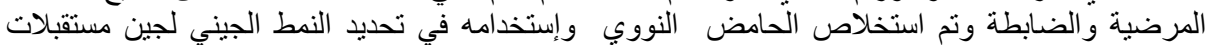

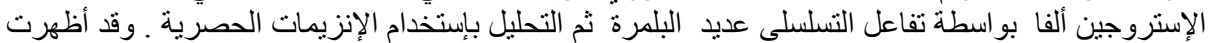

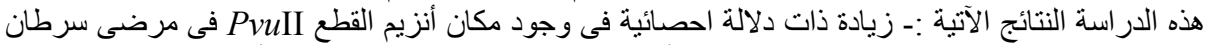

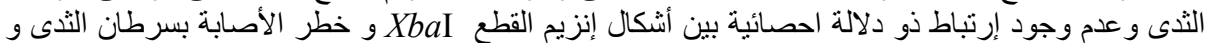

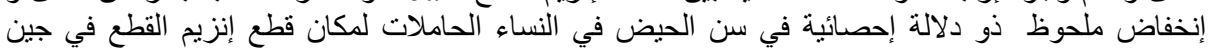

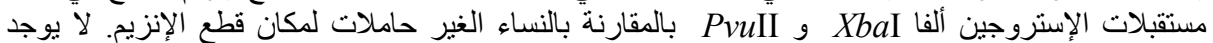

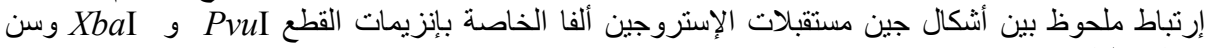

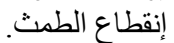
ويمكن أن نستخلص من هذه الدراسة إمكانية إستخدام إرتباط الأشكال المتعددة للجينات بسرطان الثاندان الثاب دون

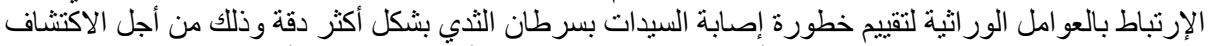

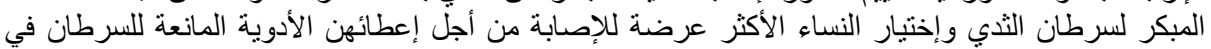
محاولة لتجنبهن الأصنابة بسرطان الثنى الغياه. 